\title{
The Effect of Problem-Based Learning Strategy on Student Learning Outcomes of SMK with Different Achievement Motivations
}

\author{
Edy Suprapto $^{1 *} \quad$ Ketut Mahendra Kuswara $^{2}$ \\ 1.Mechanical Engineering Education University of Nusa Cendana, Kupang, Indonesia \\ 2.Civil Engineering Education, University of Nusa Cendana, Kupang, Indonesia \\ Correspondence: Edy Suprapto, Nanga Jamal Street No. 2A, Kupang, NTT, Indonesia (Post Code 85118)
}

\begin{abstract}
The purpose of this study was to determine the effect of the implementation of problem-based learning strategies on the learning outcomes of Vocational High School (SMK) students who have different achievement motivation, so that the advantages of applying this strategy can be known in the learning process. This study was a Pre-Experimental Designs study with the design of the One-Group Pretest-Posttest Design (Sugiyono, 2015), which was conducted in class X TKR 1 (37 students) at State SMK 2 Kupang, academic year 2017/2018. Test requirements analysis was carried out by testing for normality and homogeneity. Data analysis techniques using $\mathrm{t}$ test analysis. To carry out the analysis in this study, it was processed with the help of a computer program SPSS for Windows version 16.0. The results of the study show that: (1) the application of problem-based learning strategies has a significant effect on groups of students with high achievement motivation; (2) the application of problem-based learning strategies has a significant influence on groups of students with low achievement motivation; (3) the application of problem-based learning strategies to groups of students with high achievement motivation and low achievement motivation had no significant differences; therefore, the application of problembased learning strategies is able to improve superior learning outcomes in students with different achievement motivation; (4) the application of problem-based learning strategies can improve students' abilities in problem solving, teamwork and high self-esteem, as well as high learning spirit. This can be observed during the learning process.
\end{abstract}

Keywords : Problem-based learning strategy, learning outcomes, different achievement motivation. DOI: $10.7176 / \mathrm{JEP} / 10-1-05$

\section{Introduction}

In the learning process is expected learners can improve the competence of knowledge, attitude, and skills, to equip himself in real life in society in order to compete and independent. This is in accordance with his opinion Reigeluth (1999), which states that learning is an attempt to change behavior which includes the addition of science, increased abilities, skills, attitudes, understandings, self-esteem, interests, character and adaptability. Meaning here, learning is a personal experience that can not be represented in others and form a meaning, process that is continuous.

But the reality is still often found the quality of learning outcomes that have not meet the required competencies, especially in Vocational High School (SMK), so less able to work in the industry or entrepreneurship. This is as revealed by Naim (2010), the quality of education in Indonesia is generally still low and needs to be improved. Furthermore, according to Nuh (2011), to increase the competency of SMK graduates that have not been sufficient, the need for additional education for one more year for internship in Industry. Furthermore, the low quality of this learning outcomes, according to Ridwan (2008), because the learning on technical and vocational education seems still oriented to teacher-centered learning, mechanistic, content-based and has not fully provided opportunities for students to develop knowledge and skills directly in the discovery in a real-life context. Students understand more lessons from notebooks, so they have not optimally developed critical and creative thinking skills and problem solving.

Responding to the low quality of education in Indonesia specifically SMK, it should be used as a foothold to reorient the learning process. The learning paradigm should emphasize student-centered learning, shifting from "teacher and what will be taught" to "student and what to do". Learning should create meaningful relationships with real life. One of the learning approaches built on the above principles is the indirect learning strategy. In this strategy the teacher serves as a facilitator and motivator of learning in the students. And students are centers of learning, ie students exploring, digging, looking for problem solving to get answers or conclusions from given learning topics.

In the learning process, learning strategy is one of the external factors that affect the learning outcomes. However, internal factors in students also affect the results of learning, such as student achievement motivation (Suprapto, 2014). Achievement motivation is a tendency in a person to achieve success and have a goal orientation. Students who have high achievement motivation will strive to achieve the best, for success in 
learning. Therefore, in order to participate improving the quality of learning outcomes in Vocational High School, then in this paper raised the title: "The Effect of Problem-Based Learning Strategy on Student Learning Outcomes of SMK with Different Achievement Motivations"

\section{Materials}

\subsection{Problem-Based Learning Strategy}

In Problem-based learning strategy, teachers function as a facilitator and motivator the occurrence of learning in students, whereas students are involved in a sequence of investigation activities to solve problems by integrating skills and concepts of content of the teaching materials. Therefore, In problem-based learning strategy, students are centers of learning. That is, students explore, search for problem solving to get answers or conclusions from a given learning topic. The problem-based learning strategy is part of contextual learning, and is a learning concept that connects subject matter to the context in which it is applied, and is associated with how one learns. According to Riyanto (2010), problem-based learning is a learning concept that helps teachers connect between material taught to real-world situations and apply that knowledge in real life. Then Owen and Smith (2010) added that, the learning outcome is a powerful learning that can develop students' intelligence, apply what is learned in accordance with real life. Then, from the results of Komalasari's research (2012), concluded, contextual learning develops students' thinking and participative skills through cooperative learning, self-study, service learning, problem-based learning, inquiry-based learning, project-based learning.

\subsection{Learning Outcomes}

According to Bloom, learning outcomes include three domains, namely cognitive, psychomotor, and affective (Krathwohl et.al., 1964). The cognitive learning outcomes is an aspect that is oriented to the ability of learners in thinking and reasoning and includes the ability of learners in remembering to solve problems / create something. This condition requires learners to combine the concepts that have been studied previously. The cognitive learning outcomes according to Bloom's revised Anderson and Krathwohl (2001) provide six categories for measuring cognitive learning outcomes: remember $(\mathrm{C} 1)$, understand $(\mathrm{C} 2)$, apply $(\mathrm{C} 3)$, analyze $(\mathrm{C} 4)$, evaluate (C5), create (C6). From various opinions on learning outcomes, the learning outcomes here are the abilities that students gain from starting levels remembering, understanding, applying, analyzing, and evaluating.

\subsection{Achievement Motivation}

One of the factors that encourage the emergence of achievement motivation in a person is the need for achievement. These needs include the desire to achieve success, overcome obstacles, solve something difficult and desire to be superior to others (Sardiman, 2007). Furthermore, according to Atkinson (1982), achievement motivation is called high if the desire for success is greater than the fear of failure. Therefore, achievement motivation is the tendency of a person to strive for success that is superior to others and has a goal orientation. In achieving success, it takes hard work and strives to the maximum extent possible to avoid failure, in order to gain optimum success. And in this study, achievement motivation in students divided into two high achievement motivation and low achievement motivation.

\section{Method}

\subsection{Research Design}

This research is a Pre-Experimental Designs Research with One-Group Pretest-Posttest Design (Sugiyono, 2015), as below.

\begin{tabular}{|c|c|c|}
\hline $\mathbf{O}_{1} \times \mathbf{O}_{2}$ & & $=$ Posttest Score \\
\hline
\end{tabular}

Figure 1. One-Group Pretest-Posttest Design model

This research was conducted on class X TKR 1 (37 students) at SMK Negeri 2 Kupang academic year 2017/2018. Implementation of experimental research includes: a) implementation of pretest and measurement of achievement motivation, b) implementation of direct instruction strategy in class X TKR 1 on students with highand low achievement motivation, c) After the learning process for 8 times meeting then done posttest in the class to measure learning outcomes.

\subsection{Research Instruments}

The research instrument is based on the subjects in the course syllabus of motorcycle. Then, developed into indicators of learning outcomes and test result learning instruments. For the achievement motivation instrument adapted from Robinson (Cohen, 1976), with indicators: 1) hope for success, 2) fear of failure, 3) hard work, and 4) competition. To measure the validity of research instrument items, product moment correlation formula was 
used, and to measure the reliability of test instrument used KR20 analysis, and reliability of achievement motivation instrument used Cronbach Alpha formula (Sugiyono, 2011).

\subsection{Data Analysis}

Prior to experimental treatment, pretest and measurement of achievement motivation were performed, to obtain a description of the initial ability of the research subjects. Test requirements analysis using: 1) normality test with Kolmogrov-Smirnov test and 2) homogeneity test with levene's test. After the data is declared normal and homogeneous, followed by data analysis with descriptive analysis and t test analysis with the help of computer program SPSS for windows version 16.0

\section{Result}

4.1 Data Description of Learning Outcomes (Pretest)

Table 1. Descriptive Analysis of Learning Outcomes Data (Pretes)

\begin{tabular}{llrrrr}
\hline & Achievement Motivation & N & Mean & Std. Deviation & Std. Error Mean \\
\hline \multirow{2}{*}{ Pretest } & High Achievement Motivation & 19 & 39.1053 & 6.06350 & 1.39106 \\
& Low Achievement Motivation & 18 & 39.6111 & 7.38153 & 1.73984 \\
\hline
\end{tabular}

(Source: Research data 2017)

From $t$ test result of two independent samples obtained price $t=-0.228$ and significance value of (Sig) $0,821(\mathrm{p}>0,05)$. This shows the results of pretest learning both groups of students with different achievement motivations, there is no significant difference (equivalent).

\subsection{Data Of Learning Outcomes (Posttest)}

From the results of research, the implementation of problem-based learning strategy in students with high achievement motivation obtained mean learning outcome is 80,63 with deviation standard 8,17 . While the student learning outcomes with low achievement motivation is mean 75,05 with standard deviation 9.96

\subsection{Results of Data Analysis}

4.3.1 Results of Analysis Requirements Test (Data of Posttest)

The result of normality test of posttest data with Kolmogorov-Smirnov test, got the score (SIG) group of students with high achievement motivation $(0,182)$ and low $(0,146)$, bigger than 0,05 , so both groups of data stated normal distribution. Levene's Test test results with the basic mean, got the number (SIG) $0.264>0.05$, then the data posttest declared homogeneous, so it can be continued with t test.

4.3.2 Hypothesis Testing Results

1. Implementation of Problem-Based Learning Strategy on High Achievement Motivation Students Table 2. Descriptive Data Analysis of Learning Outcomes (Pretest-Posttest) - High AM

\begin{tabular}{llrrrr}
\hline & & Mean & N & Std. Deviation & Std. Error Mean \\
\hline Pair 1 & Pretest & 39.1053 & 19 & 6.06350 & 1.39106 \\
& Posttest & 80.6316 & 19 & 8.17999 & 1.87662 \\
\hline
\end{tabular}

(Source: Research data 2017)

From the result of paired sample $t$ test in get $t$ value count $-32,8$, with $p$ value (Sig 2 tailed) 0,000 . With the significance level $\alpha=0.05$, it can be seen that the value of $p$ ( $\operatorname{sig} 2$ tailed) $0,000<0.05$. This shows that, the implementation of indirect insruction strategy has a significant influence on students with high achievement motivation, with mean pretest score 39.10 and posttest 80.63 .

2. Implementation of Problem-Based Learning Strategy on Low Achievement Motivation Students Table 3. Descriptive Data Analysis of Learning Outcomes (Pretest-Posttest) - Low AM

\begin{tabular}{llrrrr}
\hline & & Mean & N & Std. Deviation & Std. Error Mean \\
\hline Pair 1 & Pretest & 39.6111 & 18 & 7.38153 & 1.73984 \\
& Posttest & 75.0556 & 18 & 9.96153 & 2.34795 \\
\hline
\end{tabular}

(Source: Research data 2017)

From the result of paired sample $t$ test in get $t$ value of -29.2 , with $p$ value (Sig 2 tailed) 0.000 . With the significance level $\alpha=0.05$, it can be seen that the value of $p$ ( $\operatorname{sig} 2$ tailed) $0,000<0.05$. This shows that, the implementation of indirect insruction strategy has a significant influence on students with low achievement motivation, with mean pretest value 39.61 and posttest 75.05 . 
3. Implementation of Problem-Based Learning Strategy on Different Achievement Motivations Students Table 4. Results of Descriptive Analysis on Different Achievement Motivations

\begin{tabular}{rrrrrr}
\hline & Ac Motiv & N & Mean & Std. Deviation & Std. Error Mean \\
\hline \multirow{2}{*}{ Posttest } & AM High & 19 & 80.6316 & 8.17999 & 1.87662 \\
& AM Low & 18 & 75.0556 & 9.96153 & 2.34795 \\
\hline
\end{tabular}

(Source: Research data 2017)

From the results of the independent sample $t$ test in get the value of $t$ count 1.86 , with $p$ value (Sig 2 tailed) 0.071. With the significance level $\alpha=0.05$, it can be seen that the value of $p$ (sig 2 tailed) $0.071>0.05$. This shows that, with the implementation of indirect insruction strategy, there is no significant difference between student group with high achievement motivation (mean 80,63) and low achievement motivation (mean 75,05)

\section{Discussion}

On the application of problem-based learning strategies for groups of students with high achievement motivation is to have the initial ability score pretest (mean) 39.10 and posttest learning outcomes score (mean) 80.63. From the results of the paired sample $t$ test (table 2), the $t$-value of -32.8 is obtained, with the value of $p$ (Sig 2 tailed) 0,000 . With a significance level of $\alpha=0.05$, it can be seen that the value of $p$ ( $\operatorname{sig} 2$ tailed) $0,000<0.05$. This shows that the application of problem-based learning strategies has a significant effect on students with high achievement motivation. Therefore, the application of problem-based learning strategies to groups of students with high achievement motivation can be used in the learning process to improve students' learning outcomes.

On the application of problem-based learning strategies for groups of students with low achievement motivation is to have the initial ability score of the pretest (mean) 39.61 and the posttest learning outcome score (mean) 75.05. From the results of the paired sample $t$ test (table 3 ) the value of $t$ count is -29.21 , with the value of $\mathrm{p}$ (Sig 2 tailed) 0,000 . With a significance level of $\alpha=0.05$, it can be seen that the value of $\mathrm{p}$ ( $\operatorname{sig} 2$ tailed) $0,000<0.05$. This shows that the application of problem-based learning strategies has a significant effect on students with low achievement motivation. Therefore, the application of problem-based learning strategies to groups of students with low achievement motivation can be used in the learning process to improve student learning outcomes.

The application of problem-based learning strategies, if viewed from a group of students with high achievement motivation, found a mean of 80.63 and a group of low achievement motivation students 75.07. From the results of the t-test, two independent samples (table 4) get the value of $t$ count 1.86 , with a value of $p$ (Sig 2 tailed) 0.071 . With a significance level of $\alpha=0.05$, it can be seen that the value of $p$ (sig 2 tailed) is $0.071>0.05$. This shows that the application of problem-based learning strategies can improve learning outcomes for groups of students with different achievement motivation. Where, there was no significant difference between groups of students with high and low achievement motivation.

Therefore, it can be concluded that the problem-based learning strategy is able to improve learning outcomes in students with different achievement motivation. This is because the problem-based learning strategy is part of contextual learning that has seven main principles, namely: (1) constructivism, (2) inquiry, (3) questioning, (4) learning community, (5) modeling, (6) reflection, and (7) authentic assessment. These learning principles must be implemented in the learning process, allowing students to learn independently, learn more meaningfully, learn problem solving, and apply high-order thinking and integration from various disciplines. This process invites students to play an active role in discussing subject matter among friends to solve problems, share opinions and formulate concepts. This condition will create a conducive environmental situation to motivate students to continue learning, so that all students are encouraged to build their abilities individually and in groups. The teacher only acts as a motivator and facilitator in learning. In addition, the benefits of problembased learning that uses group work methods will train students to develop thinking power and initiatives, improve attitudes, help in understanding social behavior, and can collaborate in presenting group work. With this collaboration, students become familiar with peer tutoring activities, which are carried out alternately to explain the material mastered to other friends. On the other hand, students who are critical and creative will be able to put forward problem solving related to the material being discussed, although a little but rich in high-order thinking. In the end, the problem-based learning strategy will be able to motivate all groups of students with different achievement motivation, to continue to learn and work individually and in groups, so that they can achieve superior learning outcomes. Therefore, the problem-based learning strategy is very suitable to improve the quality of learning in students with different achievement motivation in Vocational High Schools (SMK).

The results of the above research are in line with the results of research by David, one of the teaching staff of the College of Technology in Georgia who has proven the greatness of contextual learning to develop problem-solving skills in the learning process for students (Scott, 2003). By combining problem-based learning and project-based learning, students have succeeded in creating creative products such as designing, making and flying a rocket of a certain height which is burdened with eggs and then returned to earth well without breaking the eggs. Those with high motivation have tried to use mathematical and scientific calculations as well as using 
computer programs to calculate rocket weights, rocket stability in the air and earth landing processes. The teacher here only functions as a facilitator and helps students if there are difficulties. Thus, it seems clear that in contextual learning, students are given more opportunities to solve problems according to their needs and abilities. Furthermore, the results of research by Frank \& Barzilai (2006) and Suprapto et al. (2017), in problembased learning, students will learn to use appropriate judgment and analysis for problem solving that may be more than one solution, and feel the importance of cooperation between team members in the social environment aspects. Then, from the results of his research Komalasari (2012), findings were found that: First, contextual learning in Civic Education had a significant influence on citizenship skills for junior high school students in West Java, Indonesia. Second, contextual learning develops students' thinking and participatory skills through cooperative learning, independent learning, service learning, problem-based learning, inquiry-based learning, project-based learning, and values learning strategies.

From the discussion above, it can be concluded that the application of problem-based learning strategies can significantly improve learning outcomes for students with different achievement motivation. In addition, this strategy will be able to improve teamwork capabilities, real problem solving abilities, which are very much needed in real life. And more importantly, this strategy will instill lifelong learning habits with students wherever they are. Therefore, it is recommended that teachers consider the use of problem-based learning strategies in their teaching and learning activities, to obtain superior learning outcomes for students with different achievement motivation.

\section{Conclusion}

1. Implementation of problem-based learning strategy has a significant influence on the group of students with high achievement motivation, where mean learning outcomes pretest 39.10 and posttest 80.63 , then the result of paired sample t test in get $t$ count $-32,8$, with p value (Sig 2 tailed) $0.000<0.05$.

2. Implementation of problem-based learning strategy has a significant influence on the group of students with low achievement motivation, where the mean learning outcomes pretest 39.61 and posttest 75.05 , then the results $t$ paired sample $t$ test in get $t$ value -29.21 , with $p$ value (Sig 2 tailed) $0.000<0.05$.

3. When viewed from the group of students with high achievement motivation obtained mean 80.63 and low achievement student group 75.07. From result of t test two independent samples get value of $t$ count 1,86 , with $\mathrm{p}$ value (Sig 2 tailed) 0,071>0,05. This shows that, the implementation of problem-based learning strategy in the group of students with high achievement motivation and low there is no significant difference. Therefore, the implementation of problem-based learning strategy can improve the good learning outcomes for high and low achievement motivation student.

4. Implementation of problem-based learning strategy can improve students' ability in problem solving, teamwork and high confidence, and high learning spirit. This can be observed during the learning process takes place.

\section{Acknowledgments}

We express our gratitude to the Ministry of Research Technology and Higher Education of the Republic of Indonesia, who have been willing to finance our research with the title: "The Effect of Problem-Based Learning Strategy on Student Learning Outcomes of SMK with Different Achievement Motivations".

\section{References}

Anderson, O.W. \& Krathwohl, D.R., 2001, Taxonomy for Learning, Teaching, and Assesing: A Revision of Bloom's Taxonomy of Educational Objectives. A Bridged Edition, New York: Addison WesleyLongman, Inc.

Atkinson, J., 1982, Motivation and Achievement, Washington DC: V.H. Winston and Sons.

Cohen, L., 1976, Educational Research in Classroom and School a Manual of Materials an Methods, San Fransisco: Harper \& Row Publisher.

Frank, M. \& Barzilai, 2006, A. Project-Based Technology: Instructional Strategy for Developing Tecnological Literacy, Journal of Technology Education. 18(1): 39-53. 2006.

Komalasari, K., 2012, The Effect of Contextual Learning in Civic Education on Students' Civic Skills. International Journal for Educational Studies, 4(2) 2012

Krathwohl, D.E., Bloom, B.E. \& Masia, B.B., 1964, Taxonomy of Educational Objects, The Classification of Educational Goals, Handbook II: Affective Domain. Longmans.

Naim, N., 2010, Rekonstruksi Pendidikan Nasional. Cetakan II. Yogyakarta: Penerbit Teras.

Nuh, M., 2011, SMK, Mempersiapkan Siswa Masuk Dunia Kerja. Koran Jakarta 18 Februari 2011.

Owens, T. dan Smith, A.J., 2000, Definition and Key Elements of Contextual Teaching and Learning. (on line): diakses 12 Maret 2012.

Reigeluth, C.M., 1999, Instructional-Design Theories and Models Volume II, New Jersey: Lawrence Erlbaum 
Associates, Publisher.

Ridwan., 2008, Pengaruh Model Pembelajaran (Kontekstual vs Konvensional) dan Gaya Belajar terhadap Pemahaman Konsep, Kemampuan Psikomotor dan Pemecahan Masalah pada Mahasiswa Teknik Elektro Fakultas Teknik Universitas Negeri Padang (Disertasi)., Malang: Pasca Sarjana Universitas Negeri Malang. Riyanto, Y., 2010, Paradigma Baru Pembelajaran. Jakarta: Kencana Prenada Media Group.

Sardiman A.M., 2007, Pengaruh Strategi dan Motivasi Belajar Mengajar, Jakarta: PT Raja Grafindo Persada.

Scott, J.L., 2003, Implementing Contextual Teaching and Learning: Case Study of David High School Technology Education Novice Teacher University of Georgia. (on line): http://www.coe.oga/ctl/casestudy/scottpdf. diakses: 10 April 2016.

Sugiyono, 2011, Statistika Untuk Penelitian.Cetakan ke-19, Bandung: Alfabeta.

Sugiyono., 2015, Metode Penelitian Pendidikan. Cetakan ke-21, Bandung: Alfabeta.

Suprapto, E., 2014, Pengaruh Model Pembelajaran Kontekstul Vs Pengajaran Langsung dan Motivasi Berprestasi terhadap Hasil Belajar Kognitif dan Keterampilan Motorik (Disertasi)., Malang: Pasca Sarjana Universitas Negeri Malang.

Suprapto, E., 2017, Fahrizal, Priyono, \& Basri, K. , The Aplication of Problem-Based Learning Strategy to Increase High Order Thinking Skills of Senior Vocational School Students. International Education Studies. Vol. 10, No.6, June 2017. 